\title{
The Penrose Stairway: Jorge Luis Borges at the Center of Christopher Nolan's Inception
}

\section{Brian Durán Fuentes}

The night after the news of my father's passing had crossed the border and reached me, Rocio Ramos, my unrequited love since the earlier years of my expiring youth, resurfaces into my life and practically kidnaps me to the closest movie theater. As she drives she asks me, "How do you feel?" But I can sense she doesn't expect me to answer. I have no clue. I can't even allow myself to think too much about the days on which this encounter would have been stirred me with bliss, like some perfect materialization of my wishful thinking. "I saw this the other day and knew I had to show it to you", she adds, as I stare at the fading lights outside the window. "I think you'll like it."

If I can smile about a single thing in this world is in knowing that there is someone who knows me, who can predict me. Christopher Nolan's film succeeds in capturing my attention for two and a half hours and beyond. We don't do much after the movie; we don't even say much. She has already succeeded in appealing to the cold rationalist in me. She presents me with the puzzle that is Inception, embraces me, and walks back into a world that lies beyond mine.

The first thing I do as I arrive home is re-read the next story for my World Literature class, "The Garden of Forking Paths" by Jorge Luis Borges. Doing so reaffirms a connection I began to glimpse at while I was watching the movie. This is a work that is quintessential to the author with its motif of the labyrinth and the place of the individual as a stand-in for his entire lineage, race, and ultimately, humanity. Here the Sinologist, Stephen Albert asks the protagonist, Yu Tsun: "In a riddle whose answer is chess, what is the only word that must not be used?" Treating Nolan's Inception like a similar riddle, I reach the conclusion that the works of Borges are the key to a thorough interpretation of the film, based on the subtle allusions Nolan makes to the writer's fiction, the motifs they have in common, and the recurring premise that one man is every man across history. Though this film can certainly be interpreted as a discrete entity, having Borges' work of fiction in mind is pivotal in truly understanding Nolan's directorial decisions and the poetic language he employs.

A couple of days later, I find myself in the city where my father was born, under the unfortunate task of looking after his affairs. Upon exiting the train at Bosque de Aragón Station, I climb the long stairway that leads up to the exiting bridge, facing south towards my father's neighborhood. The climb tires me out more than what I'm prepared to admit, but I get a panoramic view of the streets to locate my father's house 
behind the market.

I stretch out my hands in the darkness along the wall to find the light switch. When I turn it on, I encounter my father's ghost all around me, in bowls with crusts of leftover oatmeal on the floor, envelopes full of photos flooding the dining room table, large bottles of ketchup like red sentries by the kitchen, and more than anything, boxes upon boxes of used books for resale, dozens of them, endless possibilities within every box, any title imaginable. I stare up the stairway that caused my father's death in the twilight of his eyesight, in complete disbelief, expecting to see him in any corner, or hearing him open the door behind me. Lying on his bed, I reach into his drawer and find a single book: Ficciones de Jorge Luis Borges, in Spanish, a Borges I've never known.

I turn on my laptop and find Joshua Monet online, and old friend, a linguistics major, and a connoisseur of Western cinematography. In casual conversation, I introduce him to my interpretation of Nolan's film. I assert that the entire narrative occurs as a dream in a humility and self-deprecation. Aand yet, once I return to my father's house and peer into the endless streams of information that make up the internet, I find that others have already made the connection before me. Jaime Perales Contreras writes in his brief column for Examiner.com, "Jorge Luis Borge's influence on the movie Inception is unmistakable. In the opening scene and at the conclusion of the film, we see, for example, a physically young Leo Dicaprio having a bizarre conversation with his decrepit old alter ego. As it turns out, Borges' short story The Other, is remarkably familiar." Not only do I agree that this is an allusion to that short story, but Perales' description of Saito as the "decrepit alter ego" of Cobb corroborates my interpretation that they are in fact the same person.

I can't go on without mentioning the allusion that first inspired me find Borges in Inception, an early scene in the movie where Cobb recruits Eames, the forger for his operation, in Mombasa. Eames sits at a gambling table holding chips as Cobb approaches him from behind and says, "Rub them together all you want; they're not going to breed." This is clearly an allusion to Borges' story, "Blue Tigers," where the protagonist finds himself in the possession of blue stones described as round and smooth like coins. The narrative goes on to describe the horror on behalf of the character, as in fact, the stones keep multiplying themselves irrationally like some sort of cursed object, and how he passes on the stones to a mysterious beggar.

A third allusion occurs in a line of dialogue by Cobb after the failed extraction mission at the beginning of the film. Before getting caught and eventually hired by Saito, Cobb discusses their course of action with Arthur, stating that he plans to "lay low in Buenos Aires." I can't consider the choice of this city in the script as a mere coincidence instead of a reference to the birthplace of Borges, and consequently the setting of many of his stories such as "The South" and "Death and the Compass."

The three central motifs in Inception which coincide with those prevalent across Borges' short stories are: Dreams, labyrinths, and mirrors. Since I've driven the point that Nolan has nodded to Borges' stories within the film, it should not be taken as a coincidence that these concepts result in corresponding significations.

The most apparent motif of the three is of course, dreams. Borges' displays a constant preoccupation with the narrative and logic of dreams in stories such as "The Circular Ruins," "Ragnarok," and "Blue Tigers," to name only a few. Apart from the mechanics of dream navigation in the film, audiences should pay attention to the story's more subtle and underlying level of the dream. In his esoteric and sophisticated 
essay, "In the Mirror of the Dream: Borges and the Poetics of Kabbalah" Elliot R. Wolfson argues that Borges captures in his fiction "the belief that the phenomenal world is a dream from which one must awaken by waking to the dream that one is merely dreaming that one is awake." This goes hand in hand with the idea that Cobb is dreaming throughout the entirety of the film. Just as the protagonist of "The Circular Ruins" finds out at the end of the narrative that his reality is but a dream dreamt by the man he had created in his own dreams, Cobb has to question his own reality as the dreams of his mentor. This is reinforced by several lines in the movie that seem to break the fourth wall of the illusory reality to talk directly to Cobb: "Come back to reality" (Prof. Stephen Miles) "Who are you to say otherwise?" (The man who responds to Cobb's comment that the men in the basement don't know that they're dreaming.)

Labyrinths are perhaps Borges' most iconic motif, playing an important role in stories such as "The Garden of Forking Paths," and "The House of Asterion" representing the intricacy of perceived reality, not necessarily limited to the concept of space, but also time. Wolfson states that according to Borges, "time is perceived as an 'inexhaustible labyrinth,' which exhibits the chaos and indeterminacy of the dream." Yu Tsun comes to learn that his ancestor's labyrinth was not physical, but rather a novel that was in turn a metaphor of time; Asterion the Minotaur of Greek myth is the true victim of his labyrinth and his own naivety. Labyrinths in Inception represent the same "indeterminacy of the dream" and are in fact used by the characters for their benefit, mainly in the form of Cobb having Ariadne craft the architecture of the dreams to escape from the subconscious shadow of his wife. In other words, Cobb relies on labyrinths to escape from himself.

The significance of mirrors in Borges' fiction may best be summed up in an aphorism attributed to a heresiarch of Uqbar in "Tlön, Uqbar, Orbis Tertius" "Mirrors and copulation are abominable, for the multiply the number of mankind." Mirrors are the harsh light of consciousness, alterity, infinity, all that is uncertain and unfathomable in the universe, humans included. Eric Ormsby, in his essay "Jorge Luis Borges and the Plural I" reflects on how "one of his favorite figures for infinitude is the mirror image, that vertiginous repetition of the same mute yet glimmering reflection." The mirror is also the second gift for the poet in "The Mirror and The Mask" before his suicide. In the same vein, a mirror is what reveals Eames true form to Saito, and represents the forbidden territory to Ariadne, as Cobb warns him not to duplicate places from reality into dreams to avoid deadly repercussions.

Nevertheless, the most central aspect of this interpretation is not the recurrence of a dream, but rather a premise: A single man is all men. Many stories I have already mentioned and many others including "The Immortal" emphasize human nature and history as being independent from the notion of individuality. Homer composed the Odyssey; given infinite time, with infinite circumstances and changes, it is impossible that the Odyssey should not be composed at least once. No one is someone; a single immortal man is all men. Like Cornelius Agrippa, I am god, hero, philosopher, demon, and world -which is a long-winded way of saying that I am not. In a similar vein, "Pierre Menard, Author of the Quixote" chronicles the endeavors of a man in becoming Miguel de Cervantes and rewriting the novel, Don Quixote, ultimately reflecting that

"Every man should be capable of all ideas, and I believe that in the future he shall be."

So far, I've presented evidence to suggest that Nolan's motifs are reflective of Borges' work, but what 
insight can these fictions offer in terms of his directorial decisions under their "one man is every man" premise? In this context, Lucius Shepard has written harsh critique on the film titled "I Had Too Much To Dream Last Night" where he questions the fact that Leonardo DiCaprio is the only actor that shines in the spotlight and Cobb the only character who gets proper depth and development. "The acting is forgettable and the characters are blank slates." But Sheppard's assessment that secondary characters are neglectfully underdeveloped, such as Ariadne, whom he considers her "less a character than a plot device, inserted into the script as a surrogate audience member to provide Dom with a sounding board" is misguided since he fails to recognize that they are all part of Cobb's mind. The protagonist unknowingly approaches the author of his current reality and requests "an architect who's better than [he] was" and Miles answers by awakening a figure of innocence in Cobb's mind. Just like the Ariadne of Greek myth, the true function of this character is to guide the hero out of the labyrinth and into consciousness.

Mr. Saito, to name another example, is at once an antagonistic force and the medium for resolution in that Cobb himself is his own enemy and savior. The scene where Cobb finds Saito in Limbo as "an old man full of regret" in reality applies to Cobb if he's unwilling to wake up from the false reality in which he has lost himself.

My eyes ache as I reach this conclusion, perhaps out of strain from watching the movie. A terrible weariness overtakes me, but before I climb the stairway and to go to sleep, I find my way to the restroom. As the sunlight abandons my father's house I encounter a last image: A face in the mirror that is not my own, a wrinkled mask with eyes overtaken by the unmeasurable torrents of dreams. 


\section{Bibliography}

Borges, Jorge Luis. Collected Fictions. Ed. Andrew Hurley. New York: Viking, 1998. Print.

Ormsby, Eric. "Jorge Luis Borge and the Plural I." Twentieth-Century Literary Criticism. Ed. Linda Pavlovski and Scott T. Darga. Vol. 109. Detroit: Gale, 2001. Literature Resource Center. Web. 16 Nov. 2015.

Perales Contreras, Jaime. "Inception and Jorge Luis Borges." Examiner.com. 31 July 2010. Web. 2 Dec. 2015.

Shepar, Lucius. "I Had Too Much To Dream Last Night." Fantasy \& Science Fiction 119.5-6 (2010): 218223. Literary Reference Center. Web. 18 Nov. 2015.

Wikipedia. Wikimedia Foundation. Web. 15 Nov. 2015.

Wolfson, Elliot R. "In The Mirror Of The Dream: Borges And The Poetics Of Kabbalah." Jewish Quarterly Review 104.3 (2014): 362-379. Literary Reference Center. Web. 18 Nov. 2015 